\title{
STUDI KOMPARASI MODEL PEMBELAJARAN COOPERATIVE PROBLEM SOLVING DAN GROUP INVESTIGATION DENGAN MEMPERHATIKAN KEMAMPUAN BERPIKIR ANALISIS TERHADAP PRESTASI BELAJAR
}

\author{
(Studi Materi Kelarutan dan Hasil Kali Kelarutan (Ksp) \\ Kelas XI MIA SMA Negeri 1 Sukoharjo \\ Tahun Pelajaran 2016/2017)
}

\author{
Program Studi Pendidikan Kimia, FKIP, Universitas Sebelas Maret, Surakarta, Indonesia
}

*keperluan korespondensi, telf/fax: 081280660500, email: widiastuti_aes@staff.uns.ac.id

\begin{abstract}
ABSTRAK
Penelitian ini bertujuan untuk mengetahui ada atau tidaknya: (1) pengaruh model pembelajaran Coopertive Problem Solving (CPS) dan Group Investigation (GI) terhadap prestasi belajar peserta didik pada materi kelarutan dan hasil kali kelarutan (Ksp), (2) pengaruh kemampuan berpikir analisis terhadap prestasi belajar peserta didik pada materi kelarutan dan hasil kali kelarutan (Ksp), dan (3) interaksi antara model pembelajaran Coopertive Problem Solving (CPS) dan Group Investigation (Gl) dengan kemampuan berpikir analisis terhadap prestasi belajar peserta didik pada materi kelarutan dan hasil kali kelarutan (Ksp). Penelitian ini menggunakan metode eksperimen dengan desain faktorial 2x2. Subjek pada penelitian ini adalah peserta didik kelas XI MIA 1 dan XI MIA 2 SMA Negeri 1 Sukoharjo tahun pelajaran 2016/2017 yang diambil dengan teknik cluster random sampling. Analisis data pada penelitian ini menggunakan uji hipotesis non parametrik Kruskal Wallis. Penelitian ini menghasilkan beberapa kesimpulan, yaitu: (1) terdapat pengaruh model pembelajaran CPS dan GI terhadap prestasi belajar aspek pengetahuan dan sikap, tetapi tidak berpengaruh terhadap aspek keterampilan peserta didik, (2) tidak terdapat pengaruh kemampuan berpikir analisis tinggi dan rendah terhadap prestasi belajar peserta didik, baik aspek pengetahuan, sikap, maupun keterampilan, dan (3) terdapat interaksi antara model pembelajaran CPS dan GI dengan kemampuan berpikir analisis terhadap prestasi belajar aspek pengetahuan dan sikap, namun tidak ada interaksi antara model pembelajaran CPS dan GI dengan kemapuan berpikir analisis terhadap prestasi belajar peserta didik aspek keterampilan.
\end{abstract}

Kata Kunci: Coopertive Problem Solving (CPS), Group Investigation (GI), Kemampuan Berpikir Analisis, Prestasi Belajar, Kelarutan dan Tetapan Hasil Kali Kelarutan (Ksp)

\section{PENDAHULUAN}

Era globalisasi seperti saat ini menuntut adanya Sumber Daya Manusia (SDM) yang berkualitas, berdaya saing, keahlian professional, visioner, dan memiliki keterampilan yang memadai. Untuk mewujudkanny dapat dilakukan dengan peningkatan kualitas pendidikan. Hal ini sejalan dengan Undang-Undang nomor 20 tahun 2003 tentang Sistem Pendidikan Nasional, dimana pendidikan nasional berfungsi untuk mencerdaskan kehidupan bangsa melalui pengem- bangan kemampuan serta pembentukan watak dan peradaban yang bermartabat di tengah masyarakat dunia.

Salah satu usaha yang dilakukan pemerintah yaitu memberlakukan kurikulum 2103 yang bertujuan untuk mempersiapkan manusia Indonesia agar memiliki kemampuan hidup sebagai pribadi dan warga negara yang beriman, produktif, kreatif, inovatif, dan efektif serta mampu berkontribusi pada kehidupan bermasyarakat, berbangsa, bernegara, dan peradaban dunia. Untuk mencapai tujuan kurikulum 2013, 
pemerintah menerapkan pembelajaran dengan pendekatan saintifik (saintific approach) dengan mengamati, mananya, mencoba, mengasosiasi, dan mengkomunikasikan (5M). Untuk memperkuat pendekatan saintifik, pemerintah menyarankan untuk menggunakan model pembelajaran inkuiri (Inquiry Based Learning), model pembelajaran berbasis projek (Project Based Learning), model pembelajaran penemuan (Discovery Learning), atau model pembelajaran berbasis masalah (Problem Based Learning).

Namun keadaan di lapangan justru sebagian besar masih menggunakan model konvensional yang berpusat pada guru (teacher centered learning). Hal ini menyebabkan peserta didik kurang aktif dan cepat merasa jenuh. Akhirnya tujuan pembelajaran kurikulum 2013 tidak dapat tercapai secara maksimal untuk menjadikan peserta didik lebih aktif dan partisipasif dalam proses pembelajaran.

Kimia merupakan salah satu mata pelajaran yang diajarkan pada peserta didik Sekolah Menengah Atas (SMA) yang merupakan bagian dari ilmu sains. Kimia memuat ilmu yang mencari jawaban atas pertanyaan apa, mengapa, dan bagaimana gejala-gejala alam yang berkaitan dengan komposisi, struktur dan sifat, perubahan, dinamika, dan energi zat. Kimia merupakan ilmu yang pada awalnya diperoleh dan dikembangkan berdasarkan percobaan (induktif) namun pekembangan selanjutnya juga diperoleh dan didasarkan berdasarkan teori (deduktif). Oleh sebab itu mata pelajaran kimia melibatkan keterampilan dan penalaran. Ada dua hal yang berkaitan dengan kimia yang tidak terpisahkan, yaitu kimia sebagai produk (pengetahuan kimia berup fakta, konsep, prinsip, hukum, dan teori) temuan ilmuwan dan kimia sebagai proses (kerja ilmiah). Hal ini menyebabkan pembelajaran kimia dan penilaian hasil belajar kimia harus memperhatikan karakteristik ilmu kimia sebagai proses dan produk [1]

Kelarutan dan Hasil Kali Kelarutan merupakan salah satu mata pelajaran kimia SMA yang termasuk dalam menguji kemampuan mendeskripsikan kinetika reaksi, kesetimbangan kimia, dan faktor-faktor yang mempengaruhinya, serta penerapannya dalam kehidupan sehari-hari dan industri. Menurut guru SMA Negeri 1 Sukoharjo materi ini termasuk mata pelajaran yang sulit bagi peserta didik kelas XI semester genap disamping materi buffer dan hidrolisis. Hal ini disebabkan materi ini merupakan materi yang menuntut peserta didik agar dapat menggabungkan antara penguasaan konsep-konsep kimia dan mengaplikasikannya dalam perhitungan kimia. Apabila siswa kurang menguasai konsep yang ada maka siswa akan mengalami kesulitan untuk menyelesaikan soal-soal yang berkaitan dengan konsep materi kelarutan dan hasil kali kelarutan.

Selain dari karakteristik materi kelarutan dan hasil kali kelarutan itu sendiri, model pembelajaran yang digunakan guru dalam menyampaikan materi tersebut juga mempengaruhi tingkat penguasaan peserta didik pada materi tersebut. Berdasarkan hasil observasi, pembelajaran kimia SMA Negeri 1 Sukoharjo sebagian besar menggunakan metode ceramah dan diskusi interaktif serta drill and practice terutama pada materi hitungan kimia. Metode demikian memang baik terutama untuk peserta didik yang mudah menangkap dan mengerti apa yang disampaikan guru, namun bagi siswa yang sulit memahaminya akan cenderung pasif dan acuh terhadap materi tersebut. Oleh karena itu dibutuhkan model pembelajaran yang sesuai dalam menyajikan kompetensi dasar ini agar tujuan pembelajaran dapat tercapai secara maksimal dan menjadikan peserta didik lebih aktif dan partisipasif dalam proses pembelajaran, sesuai yang dikehendaki kurikulum 2013.

Cooperative problem solving (CPS) dapat menjadi salah satu alternatif model pembelajaran. Model pembelajaran problem solving merupakan suatu cara penyajian pembelajaran dengan mendrong siswa untuk mencari dan memecahkan suatu masalah dalam rangka pencapaian tujuan pembelajaran [2]. Model pembelajaran CPS mendorong peserta didik untuk mencari dan memecahkan masalah atau persoalan dengan bekerja sama atau berkelompok. 
Model pembelajaran ini menuntut peserta didik untuk aktif memecahkan masalah secara berkelompok sehingga memperoleh pengetahuan. Model pembelajaran ini termasuk model pembelajaran berdasarkan masalah yang dilakukan dengan cara pemecahan masalah dimana merupakan model pembelajaran yang dianjurkan pemerintah pada kurikulum 2013. Penelitian sebelumnya menunjukkan bahwa penerapan model pembelajaran cooperative problem solving dapat meningkatkan prestasi belajar peserta didik dibandingkan dengan model konvensional [3].

Group investigation merupakan model pembelajaran yang melibatkan siswa sejak perencanaan, baik dalam menentukan topik maupun cara mempelajarinya melalui investigasi. Model ini menuntut para siswa untuk memiliki kemampuan yang baik dalam berkomunikasi maupun dalam keterampilan proses kelompok (group process skill) [2]. Metode ini dipandang sebagai model pembelajaran kooperatif yang paling kompleks dan paling sulit dilaksanakan. Group investigation juga menuntut peserta didik untuk aktif dalam pembelajaran namun dalam model pembelajaran ini peran serta guru dalam diskusi lebih besar dibanding dalam cooperative problem solving. Oleh sebab itu model ini tidak termasuk yang dianjurkan dalam kurikulum 2013. Penelitian sebelumnya mengatakan bahwa model pembelajaran Group Investigation (GI) lebih baik dalam meningkatkan hasil belajar siswa dibandingkan model konvensional [4].

Model pembelajaran kooperatif dapat meningkatkan kemampuan berpikir siswa [5], termasuk CPS dan GI. Pembelajaran berbasis masalah secara signifikan dapat meningkatkan kemampuan berpikir analisis peserta didik [6] Penerapan model pembelajaran Cooperative Problem Solving diharapkan dapat melatih siswa dalam memecahkan masalah sehingga siswa dapat terbiasa untuk berpikir secara analisis yang pada akhirnya dapat membuat siswa lebih mudah memahami permasalahan dalam kimia [7]. Penerapan model pembelajaran Gl dapat meningkatkan kemam- puan berpikir analisis peserta didik [8]. Berpikir adalah proses yang dinamis yang dapat dilukiskan menurut proses atau jalannya [9]. Dalam Permendikbud No 104 tahun 2014, menganalisis adalah menggunakan keterampilan yang telah dipelajarinya terhadap suatu informasi yang belum diketahuinya dalam mengelompokkan informasi, menentukan keterhubungan antara satu kelompok atau informasi dengan kelompok atau informasi lainnya, antara fakta dengan konsep, antara argumen dengan kesimpulan, benang merah pemikiran antara satu karya dengan karya lainnya. Dari definisi tersebut dapat disimpulkan bahwa kemampuan berpikir analisis merupakan suatu proses kognitif yang dinamis dalam menggunakan keterampilan yang telah dipelajarinya terhadap suatu informasi yang belum diketahuinya dalam mengelompokkan informasi, menentukan keterhubungan antara satu kelompok atau informasi dengan kelompok atau informasi lainnya, antara fakta dengan konsep, antara argumen dengan kesimpulan, benang merah pemikiran antara satu karya dengan karya lainnya.

Tidak dapat dipungkiri bahwa tidak semua peserta didik mempunyai kemampuan berpikir analisis yang tinggi. Coopertive problem solving dan group investigation merupakan dua model pembelajaran yang menuntut peserta didik untuk berpikir analisis. Selain itu, materi kelarutan dan hasil kali kelarutan juga membutuhkan kemampun berpikir analisis, terutama dalam mengerjakan soal peserta didik dituntut untuk mengidentifikasi soal kemudian memilih konsep atau rumus mana yang sesuai untuk menyelesaikan soal tersebut serta menghubungkannya dengan kehidupan sehari-hari.

Berdasarkan uraian latar belakang di atas maka perlu dilakukan penelitian untuk mengetahui prestasi belajar peserta didik menggunakan model pembelajaran problem solving dan group investigation ditinjau dari kemampuan berpikir analisis pada materi kelarutan dan tetapan hasil kali kelarutan (Ksp) di SMA Negeri 1 Sukoharjo. 


\section{METODE PENELITIAN}

Penelitian ini dilaksanakan di SMA Negeri 1 Sukoharjo, Jalan Pemuda nomor 38 Jetis, Sukoharjo pada kelas XI MIA semester genap tahun pelajaran 2016/2017. Metode penelitian yang digunakan adalah metode eksperimen dengan desain faktorial $2 \times 2$. Adapun bagan desain penelitian disajikan pada Tabel 1.

Waktu penelitian dilaksanakan pada Maret 2017 sampai Mei 2018 dengan subjek penelitian yaitu peserta didik kelas XI MIA 1 yang berjumlah 39 peserta didik dan dan XI MIA 2 yang berjumlah 38 peserta didik. dengan pertimbangan bahwa kedua kelas tersebut memiliki kemampuan yang sama. Kelas XI MIA 1 (Kelas Eksperimen I) dan diberikan model pembelajaran CPS dan Kelas XI MIA 2 (Kelas Eksperimen II) diberikan model pembelajaran GI.

Tabel 1. Rancangan Penelitian Desain Faktorial 2x2

\begin{tabular}{|c|c|c|c|}
\hline \multirow{2}{*}{$\begin{array}{l}\text { Kelas } \\
\text { Eks. }\end{array}$} & \multirow{2}{*}{$\begin{array}{c}\text { Model } \\
\text { Pembelajaran } \\
\text { (A) }\end{array}$} & \multicolumn{2}{|c|}{$\begin{array}{l}\text { Kemampuan } \\
\text { Berpikir Analisis } \\
\text { (B) }\end{array}$} \\
\hline & & $\begin{array}{c}\text { Tinggi } \\
\left(B_{1}\right)\end{array}$ & $\begin{array}{c}\text { Rendah } \\
\left(\mathrm{B}_{2}\right)\end{array}$ \\
\hline 1 & $\operatorname{CPS}\left(A_{1}\right)$ & $A_{1} B_{1}$ & $\mathrm{~A}_{1} \mathrm{~B}_{2}$ \\
\hline II & $\mathrm{GI}\left(\mathrm{A}_{2}\right)$ & $\mathrm{A}_{2} \mathrm{~B}_{1}$ & $\mathrm{~A}_{2} \mathrm{~B}_{2}$ \\
\hline
\end{tabular}

\section{HASIL DAN PEMBAHASAN}

Data dari penelitian ini adalah nilai kemampuan berpikir analisis dan prestasi belajar peserta didik materi Kelarutan dan Tetapan Hasil Kali Kelarutan (Ksp) yang meliputi aspek pengetahuan, sikap, dan keterampilan. Berikut ini disajikan data hasil penelitian dari masing-masing variabel.

\section{Data Prestasi Belajar Aspek Pengetahuan}

Pada kelas eksperimen I, nilai aspek pengetahuan peserta didik tertinggi adalah 4,00 dan terendah adalah 1,40 dengan nilai rata-rata 3,12. Pada kelas eksperimen II nilai aspek pengetahuan tertinggi adalah 4,00 dan terendah adalah 2,00 dengan rata-rata
2,98. Perbandingan distribusi frekuensi prestasi pengetahuan dapat dilihat pada Tabel 2 dan histogram perbandingan prestasi pengetahuan disajikan pada Gambar 1.

\section{Data Prestasi Belajar Aspek Sikap}

Pada kelas eksperimen I, nilai aspek sikap tertinggi adalah 4,00 dan dan nilai terendah adalah 2,00 dengan nilai rata-rata 2,97. Pada kelas eksperimen II, nilai aspek sikap tertinggi adalah 4,00 dan dan nilai terendah adalah 3,00 dengan nilai rata-rata 3,44. Perbandingan distribusi frekuensi prestasi sikap dapat dilihat pada Tabel 3 dan histogram perbandingan prestasi sikap disajikan pada Gambar 2.

\section{Data Prestasi Belajar Aspek Keterampilan}

Pada kelas eksperimen I, nilai aspek keterampilan tertinggi adalah 4,00 dan dan nilai terendah adalah 3,20 dengan nilai rata-rata 3,87 . Pada kelas eksperimen II, nilai aspek keterampilan tertinggi adalah 4,00 dan dan terendah adalah 3,20 dengan nilai rata-rata 3,90. Perbandingan distribusi frekuensi prestasi keterampilan dapat dilihat pada Tabel 4 dan histogram perbandingan prestasi keterampilan disajikan pada Gambar 3.

\section{Pengujian Hipotesis}

Pengujian hipotesis dilakukan dengan analisis variansi dua jalan (ANAVA) dengan sel tak sama. Sebelum dilakukan uji ANAVA, terdapat beberapa persyarata analisis yang hars dipenuhi, yaitu uji normalitas dan homogenitas variansi.. Uji normalitas dan homogenitas dilakukan dengan bantuan software IBM SPSS v.24. Uji normalitas bertujuan untuk mengetahui data penelitian normal atau tidak, sedangkan uji homogenitas utuk mengetahui data penelitian mempunyai variansi yang sama atu tidak. Untuk data yang tidak memenuhi prasyarat analsisi tersebut maka pengujian hipotesis dilskuksn dengan uji statistik non parametrik Kruskal Wallis Hasil uji normalitas disajikan pada Tabel 5. dan hasil uji homogenitas variansi disajikan pada Tabel 6. 
Tabel 2. Perbandingan Distribusi Frekuensi Prestasi Pengetahuan Peserta Didik

\begin{tabular}{|c|c|c|c|c|}
\hline \multirow[b]{2}{*}{ No. } & \multirow[b]{2}{*}{ Interval } & \multirow[b]{2}{*}{$\begin{array}{c}\text { Nilai } \\
\text { Tengah }\end{array}$} & \multicolumn{2}{|c|}{ Frekuensi } \\
\hline & & & $\begin{array}{c}\text { Eks. } \\
\text { I }\end{array}$ & $\begin{array}{c}\text { Eks. } \\
\text { II }\end{array}$ \\
\hline 1 & $0,6-1,0$ & 0,8 & 0 & 0 \\
\hline 2 & $1,1-1,5$ & 1,3 & 2 & 0 \\
\hline 3 & $1,6-2,0$ & 1,8 & 2 & 1 \\
\hline 4 & $2,1-2,5$ & 2,3 & 4 & 4 \\
\hline 5 & $2,6-3,0$ & 2,8 & 6 & 22 \\
\hline 6 & $3,1-3,5$ & 3,3 & 11 & 8 \\
\hline 7 & $3,6-4,0$ & 3,8 & 13 & 4 \\
\hline \multicolumn{3}{|c|}{ Jumlah } & 38 & 39 \\
\hline
\end{tabular}

Tabel 3. Perbandingan Distribusi Frekuensi Prestasi Sikap Peserta Didik

\begin{tabular}{cccc}
\hline \multirow{2}{*}{ No. } & \multirow{2}{*}{ Nilai } & \multicolumn{2}{c}{ Frekuensi } \\
\cline { 3 - 4 } & & Eks. I & Eks. II \\
\hline 1. & 1 & 0 & 0 \\
2. & 2 & 2 & 0 \\
3. & 3 & 35 & 22 \\
4. & 4 & 1 & 17 \\
\hline \multicolumn{2}{c}{ Jumlah } & 38 & 39 \\
\hline
\end{tabular}

Tabel 4. Perbandingan Distribusi Frekuensi Prestasi Keterampilan Peserta Didik

\begin{tabular}{|c|c|c|c|c|}
\hline \multirow[b]{2}{*}{ No. } & \multirow[b]{2}{*}{ Interval } & \multirow[b]{2}{*}{$\begin{array}{l}\text { Nilai } \\
\text { Tengah }\end{array}$} & \multicolumn{2}{|c|}{ Frekuensi } \\
\hline & & & $\begin{array}{c}\text { Eks. } \\
1\end{array}$ & $\begin{array}{c}\text { Eks } \\
\text { II }\end{array}$ \\
\hline 1 & $2,7-2,8$ & 2,75 & 0 & 0 \\
\hline 2 & $2,9-3,0$ & 2,95 & 0 & 0 \\
\hline 3 & $3,1-3,2$ & 3,15 & 2 & 1 \\
\hline 4 & $3,3-3,4$ & 3,35 & 0 & 0 \\
\hline 5 & $3,5-3,6$ & 3,55 & 5 & 0 \\
\hline 6 & $3,7-3,8$ & 3,75 & 4 & 9 \\
\hline 7 & $3,9-4,0$ & 3,95 & 27 & 29 \\
\hline & Jumlal & & 38 & 39 \\
\hline
\end{tabular}

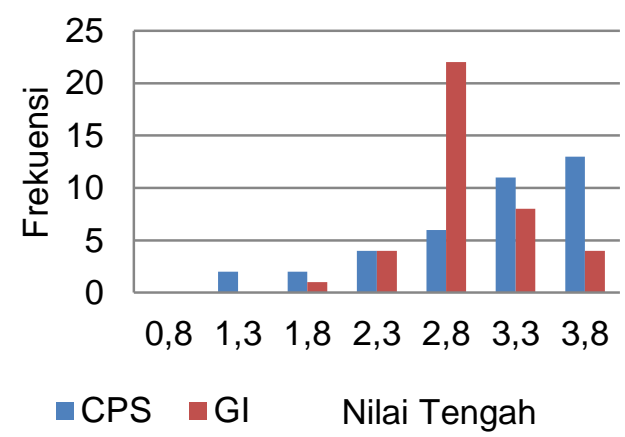

Gambar 1. Perbandingan Prestasi Pengetahuan Kelas Eksperimen

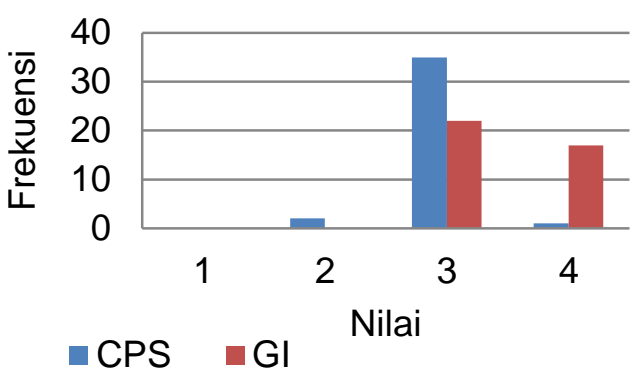

Gambar 2. Perbandingan Prestasi Sikap Kelas Eksperimen

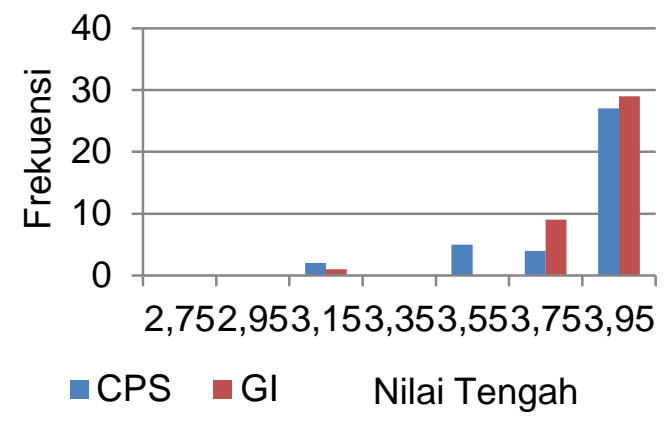

Gambar 3. Perbandingan Prestasi Keterampilan Kelas Eksperimen

Berdasarkan Tabel 5 dan Tabel 6, data penelitian tidak ememnuhi prasyarat analisis sehingga pengujian hipotesis dilakukan dengan statistik non parametrik Kruskal Wallis

\section{Hipotesis Pertama}

Berdasarkan hasil uji statstik non parametrik Kruskal Wallis untuk pengaruh model pembelajaran terhadap prestasi pengetahuan, diperoleh nilai Asymp. Sig. $(0,040)<\alpha(0,050)$ maka $\mathrm{H}_{0 \mathrm{~A}}$ ditolak. Berdasarkan data tersebut dapat disimpulkan bahwa terdapat pengaruh model pembelajaran CPS dan GI terhadap prestasi belajar aspek pengetahuan pada materi kelarutan dan tetapan hasil kali kelarutan. Hal ini sejalan dengan penelitian sebelumnya yang menyatakan bahwa model pembelajaran CPS dan GI mempunyai pengaruh yang berbeda terhadap prestasi belajar peserta didik [6].

Kelas eksperimen I yang diterapkan model pembelajaran CPS mempunyai nilai rata-rata prestasi belajar aspek pengetahuan sebesar 3,12 sedangkan kelas eksperimen II yang diterapkan model pembelajaran Gl 
mempunyai nilai rata-rata prestasi belajar aspek pengetahuan sebesar 2,98.

Pada kelas yang diterapkan model pembelajaran Cooperative Problem Solving (CPS) peserta didik dihadapkan dengan masalah yang berupa soal-soal kelarutan dan tetapan hasil kali kelarutan, baik berupa teori maupun perhitungan. Dengan adanya masalah ini berarti peserta didik ditempatkan pada lingkungan yang memaksa untuk menggunakan mempraktikkan kemampuannya untuk menyelesaikan masalah [10]. Dengan berdiskusi bersama kelompok, peserta didik yang kurang paham bisa bertanya kepada teman yang lebih paham. Selain itu, dengan model pembelajaran CPS peserta didik lebih terlatih untuk menyelesaikan soal dengan benar. Dalam pelaksanaannya sebagian besar peserta didik antusias dalam berdiskusi memecahkan masalah yang diberikan guru, namun ada beberapa siswa yang kurang aktif dan hanya menunggu peserta didik lain menyelesaikan masalah tersebut.

Pada kelas yang diterapkan model pembelajaran Group Investigation (GI) peserta didik melakukan investigasi terhadap suatu topik dimana peserta didik dilibatkan sejak perencanaan, baik menentukan topik maupun cara mempelajarinya dengan pengawasan guru yang memastikan investigasi berjalan dengan baik. Walaupun topik sudah ditentukan guru, sub topik sudah ditentukan bersama guru, dan sudah dipilih peserta didik, namun peserta didik bersama kelompoknya sendiri yang memutuskan isi materi dari sub topik yang telah dipilih berdasarkan sumbersumber belajar yang digunakan. Jadi peserta didik harus pandai memilih materi yang baik dan mudah dipahami. Dalam pelaksanannya sebagian peserta didik antusias untuk melakukan investigasi mengenai topik yang dipilih, namun sebagian peserta didik kurang antusias untuk melakukan investigasi.

Berdasarkan hasil uji statstik non parametrik Kruskal Wallis untuk pengaruh model pembelajaran terhadap prestasi sikap, diperoleh nilai Asymp. Sig nilai Asymp. Sig.. $(0,000)<\alpha(0,050)$ maka $\mathrm{H}_{0 \mathrm{~A}}$ ditolak. Bedasarkan data tersebut dapat disimpulkan bahwa terdapat pengaruh model pembelajaran CPS dan GI terhadap prestasi belajar aspek sikap pada materi kelarutan dan tetapan hasil kali kelarutan.. Kelas yang diterapkan model pembelajaran CPS mempunyai rata-rata prestasi belajar aspek sikap 2,97 sedangkan kelas yang diterapkan model pembelajaran Gl adalah 3,44.

Tabel 5. Hasil Uji Normalitas Prestasi Belajar Peserta Didik Kelas Eksperimen I (CPS) dan Eksperimen II (GI)

\begin{tabular}{cccccccc}
\hline $\begin{array}{c}\text { Kelompok } \\
\begin{array}{c}\text { Peserta } \\
\text { Didik }\end{array}\end{array}$ & $\alpha$ & Sig. & Kesimpulan & Sig. & Kesimpulan & Sig. & Kesimpulan \\
\cline { 3 - 8 } & & & \multicolumn{2}{c}{ Pengetahuan } & \multicolumn{2}{c}{ Sikap } & \multicolumn{2}{c}{ Keterampilan } \\
\hline $\mathrm{A}_{1}$ & 0,050 & 0,077 & Normal & 0,000 & Tidak Normal & 0,000 & Tidak Normal \\
$\mathrm{A}_{2}$ & 0,050 & 0,017 & Tidak Normal & 0,000 & Tidak Normal & 0,000 & Tidak Normal \\
$\mathrm{B}_{1}$ & 0,050 & 0,276 & Normal & 0,000 & Tidak Normal & 0,000 & Tidak Normal \\
$\mathrm{B}_{2}$ & 0,050 & 0,035 & Tidak Normal & 0,000 & Tidak Normal & 0,000 & Tidak Normal \\
$\mathrm{A}_{1} \mathrm{~B}_{1}$ & 0,050 & 0,276 & Normal & 0,000 & Tidak Normal & 0,000 & Tidak Normal \\
$\mathrm{A}_{1} \mathrm{~B}_{2}$ & 0,050 & 0,028 & Tidak Normal & 0,000 & Tidak Normal & 0,000 & Tidak Normal \\
$\mathrm{A}_{2} \mathrm{~B}_{1}$ & 0,050 & 0,772 & Normal & 0,000 & Tidak Normal & 0,000 & Tidak Normal \\
$\mathrm{A}_{2} \mathrm{~B}_{2}$ & 0,050 & 0,027 & Tidak Normal & 0,000 & Tidak Normal & 0,000 & Tidak Normal \\
\hline
\end{tabular}


Tabel 6. Hasil Uji Homogenitas Prestasi Belajar Peserta Didik Kelas Eksperimen I (CPS) dan Eksperimen II (Gl)

\begin{tabular}{|c|c|c|c|c|c|c|c|}
\hline \multirow{2}{*}{$\begin{array}{c}\text { Uji } \\
\text { Homogenitas }\end{array}$} & \multirow{2}{*}{$\alpha$} & \multicolumn{2}{|c|}{ Pengetahuan } & \multicolumn{2}{|r|}{ Sikap } & \multicolumn{2}{|c|}{ Keterampilan } \\
\hline & & Sig. & Kesimpulan & Sig. & Kesimpulan & Sig. & Kesimpulan \\
\hline $\begin{array}{l}\text { Ditinjau dari } \\
\text { Model } \\
\text { Pembelajaran }\end{array}$ & 0,050 & 0,053 & Homogen & 0,000 & $\begin{array}{l}\text { Tidak } \\
\text { Homogen }\end{array}$ & 0,007 & $\begin{array}{c}\text { Tidak } \\
\text { Homogen }\end{array}$ \\
\hline $\begin{array}{l}\text { Ditinjau dari } \\
\text { Kemampuan } \\
\text { Berpikir } \\
\text { Analisis }\end{array}$ & 0,050 & 0,438 & Homogen & 0,970 & Homogen & 0,220 & Homogen \\
\hline $\begin{array}{l}\text { Ditinjau dari } \\
\text { Antar Sel }\end{array}$ & 0,050 & 0,028 & $\begin{array}{c}\text { Tidak } \\
\text { Homogen }\end{array}$ & 0,000 & $\begin{array}{c}\text { Tidak } \\
\text { Homogen }\end{array}$ & 0,015 & $\begin{array}{c}\text { Tidak } \\
\text { Homogen }\end{array}$ \\
\hline
\end{tabular}

Berdasarkan hasil uji statstik non parametrik Kruskal Wallis untuk pengaruh model pembelajaran terhadap prestasi keterampilan diperoleh nilai Asymp. Sig. $(0,366)>\alpha(0,050)$ maka $\mathrm{H}_{0 \mathrm{~A}}$ diterima. Bedasarkan data tersebut dapat disimpulkan bahwa tidak terdapat pengaruh model pembelajaran CPS dan Gl terhadap prestasi belajar aspek keterampilan pada materi kelarutan dan tetapan hasil kali kelarutan. Kelas yang diterapkan model pembelajaran CPS mempunyai rata-rata prestasi belajar aspek keterampilan 3,868, sedangkan kelas yang diterapkan model pembelajaran Gl adalah 3,920 (Tabel 4.8). Hal ini menunjukkan bahwa peserta didik dengan model pembelajaran CPS maupun GI mempunyai prestasi belajar yang tinggi.

\section{Hipotesis Kedua}

Berdasarkan hasil uji statstik non parametrik Kruskal Wallis untuk pengaruh kemampuan berpikir analisis terhadap prestasi pengetahuan diperoleh nilai Asymp. Sig. $(0,099)>\alpha$ $(0,050)$ maka $\mathrm{H}_{0 \mathrm{~B}}$ diterima. Bedasarkan data tersebut dapat disimpulkan bahwa tidak terdapat pengaruh kemampuan berpikir analisis terhadap prestasi belajar aspek pengetahuan pada materi kelarutan dan tetapan hasil kali kelarutan. Besarnya rata-rata nilai prestasi aspek pengetahuan peserta didik pada kelompok kemampuan berpikir analisis tinggi adalah 3,125 sedangkan pada kelompok peserta didik dengan kemampuan berpikir analisis rendah adalah 2,879 . Dalam penelitian ini diperoleh simpulan bahwa peserta didik dengan kemampuan berpikir analisis tinggi maupun rendah bisa mempunyai prestasi belajar aspek pengetahuan yang tinggi ataupun rendah.

Berdasarkan hasil uji statstik non parametrik Kruskal Wallis untuk pengaruh kemampuan berpikir analisis terhadap prestasi sikap diperoleh nilai Asymp. Sig. $(0,399)>(0,050)$ maka $\mathrm{H}_{0 \mathrm{~B}}$ diterima. Bedasarkan data tersebut dapat disimpulkan bahwa tidak terdapat pengaruh kemampuan berpikir analisis terhadap prestasi belajar aspek sikap pada materi kelarutan dan tetapan hasil kali kelarutan. Besarnya rata-rata nilai prestasi belajar aspek sikap pada kelompok berpikir analisis tinggi yaitu 3,250 sedangkan pada pada kelompok kemampuan berpikir analisis rendah adalah 3,138. Hal ini menunjukkan bahwa kelompok peserta didik dengan kemampuan berpikir analisis yang tinggi maupun rendah bisa mempunyai prestasi belajar yang tinggi ataupun rendah.

Berdasarkan hasil uji statstik non parametrik Kruskal Wallis untuk pengaruh kemampuan berpikir analisis terhadap prestasi keterampilan diperoleh nilai Asymp. Sig Nilai Asymp Sig. (0,902) $>\alpha \quad(0,050)$ maka $H_{O B}$ diterima. Bedasarkan data tersebut dapat disimpulkan bahwa tidak terdapat pengaruh keapuan berpikir analisis terhadap prestasi belajar aspek keterampilan pada materi kelarutan dan tetapan hasil kali kelarutan.

Besarnya rata-rata nilai prestasi keterampilan peserta didik dengan kemampuan berpikir analisis tinggi adalah 3,900 sedangkan pada peserta 
didik dengan kemampuan berpikir analisis rendah adalah 3,886 . Hal ini menunjukkan bahwa kelompok peserta didik dengan kemampuan berpikir analisis tinggi mempunyai nilai aspek keterampilan hampir sama dengan kelompok peserta didik dengan kemampuan berpikir analisis rendah. dengan kata lain, peserta didik dengan kemampuan berpikir analisis tinggi dan rendah masing-masing dapat memiliki nilai prestasi belajar aspek keterampilan yang tinggi maupun rendah.

\section{Hipotesis Ketiga}

Berdasarkan hasil uji statstik non parametrik Kruskal Wallis untuk interaksi model pembelajaran dengan kemampuan berpikir analisis terhadap prestasi pengetahuan diperoleh nilai Asymp $(0,030)<\alpha(0,050)$ maka $\mathrm{H}_{O A}$ ditolak. Bedasarkan data tersebut dapat disimpulkan bahwa terdapat interaksi antara model pembelajaran CPS dan GI dengan kemampuan berpikir analisis terhadap prestasi belajar aspek pengetahuan pada materi kelarutan dan tetapan hasil kali kelarutan.

Peserta didik dengan kemampuan berpikir analisis tinggi pada kelas eksperimen I dengan model pembelajaran CPS mempunyai nilai aspek pengetahuan rata-rata 3,120 sedangkan pada kelas eksperimen II dengan model pembelajaran GI mempunyai nilai aspek pengetahuan rata-rata 3,130 . Hal ini menunjukan bahwa peserta didik yang mempunyai kemampuan berpikir analisis tinggi mempunyai nilai yang lebih baik apabila diberi model pembelajaran GI daripada CPS.

Model pembelajaran Cooperative Problem Solving (CPS) peserta didik dihadapkan pada masalah yang berupa soal-soal kemudian peserta didik dituntut untuk memecahkannya bersama kelompok. Sedangkan pada model pembelajaran Group Investigation (GI) melibatkan peserta didik dari awal investigasi, bahkan dari awal perencanaan investigasi dengan bimbingan dari guru. Meskipun pada model pembelajaran CPS peran guru lebih minim dibanding pada model pembelajaran GI, namun dengan adanya soal yang sudah disediakan oleh guru menyebabkan pemikiran peserta didik lebih terarah dan peserta didik tinggal memecahkannya sehingga peserta didik yang mempunyai kemampuan berpikir yang rendah pun mampu memahami materi kelarutan dan tetapan hasil kali kelarutan sehingga memperoleh nilai pengetahuan yang baik.

Pada model pembelajaran GI, walaupun topik sudah ditentukan guru, sub topik sudah ditentukan bersama guru, dan sudah dipilih peserta didik, namun peserta didik bersama kelompoknya sendiri yang memutuskan isi materi dari sub topik yang telah dipilih berdasarkan sumber-sumber belajar yang digunakan. Selain itu peserta didik diminta untuk membuat soal sekaligus jawaban yang benar. Oleh karena itu dalam menjalankan model pembelajaran GI dibutuhkan kemampuan berpikir analisis yang tinggi untuk menentukan isi materi dari sub topik yang telah dipilh dan membuat soal yang baik dengan jawaban yang benar. Sedangkan peserta didik yang mempunyai kemampuan berpikir analisis yang rendah kurang bisa mengikuti proses investigasi sehingga kurang memahami materi.

Berdasarkan hasil uji statstik non parametrik Kruskal Wallis untuk interaksi model pembelajaran dengan kemampuan berpikir analisis terhadap prestasi pengetahuan diperoleh nilai Asymp. Sig. $(0,000)<\alpha(0,050)$ maka $\mathrm{H}_{0 \mathrm{~A}}$ ditolak. Bedasarkan data tersebut dapat disimpulkan bahwa terdapat interaksi antara model pebelajaran CPS dan GI dengan kemampuan berpikir analsisis terhadap prestasi belajar aspek sikap pada materi kelarutan dan tetapan hasil kali kelarutan.

Berdasarkan hasil uji statstik non parametrik Kruskal Wallis untuk interaksi model pembelajaran dengan kemampuan berpikir analisis terhadap prestasi pengetahuan diperoleh nilai Asymp. Sig. $(0,817)>\alpha(0,050)$ maka $\mathrm{H}_{0 A}$ diterima. Bedasarkan data tersebut dapat disimpulkan bahwa tidak terdapat interaksi antara model pebelajaran CPS dan Gl dengan kemampuan berpikir analsisis terhadap prestasi belajar aspek 
keterampilan pada materi kelarutan dan tetapan hasil kali kelarutan.

\section{KESIMPULAN}

Berdasarkan hasil penelitian dapat disimpulkan bahwa: (1) terdapat pengaruh model pembelajaran CPS dan Gl terhadap prestasi belajar aspek pengetahuan dan sikap, tetapi tidak berpengaruh terhadap aspek keterampilan peserta didik, (2) tidak terdapat pengaruh kemampuan berpikir analisis tinggi dan rendah terhadap prestasi belajar peserta didik, baik aspek pengetahuan, sikap, maupun keterampilan, (3) terdapat interaksi antara model pembelajaran CPS dan GI dengan kemampuan berpikir analisis terhadap prestasi belajar aspek pengetahuan dan sikap, namun tidak ada interaksi antara model pembelajaran CPS dan GI dengan kemapuan berpikir analisis terhadap prestasi belajar peserta didik aspek keterampilan.

\section{UCAPAN TERIMA KASIH}

Ibu Sri Soewarsih, M. Pd. selaku kepala SMA Negeri 1 Sukoharjo yang telah memberikan izin penelitian serta Ibu Suyanti, S. Pd., M. Pd. selaku guru mata pelajaran kimia yang telah memberikan izin untuk melakukan penelitian di kelas yang diampu.

\section{DAFTAR RUJUKAN}

[1] Mulyasa, E.. (2013). Menjadi Guru Profesional Menciptakan Pembelajaran Kreatif dan Menyenangkan. Bandung: PT Remaja Rosdakarya.

[2] Hamdani. (2010). Strategi Belajar Mengajar. Bandung: Pustaka Setia.

[3] Esan, Femi. (2015). Cooperative Problem-Soving Strategy and Student's Learning Outcomes in Algebraic Word Problem: A Nigerian Case. International Journal for Infonomic (IJI), 8 (1), 986-989.
[4] Budi, Lina; Yamtinah, Sri; dan Redjeki, Tri. (2013). Pengaruh Metode Pembelajaran Group Investigation (GI) dan Minat terhadap Prestasi Belajar Siswa pada Pokok Bahasan Struktur Atom dan Sistem Periodik Kelas XI SMA N 6 Surakarta Tahun Pelajaran 2012/2013. Jurna Pendidikan Kimia, 2 (3), 10-18.

[5] Sunhaji. (2016). Implementation of Cooperative Learning Strategy in Forming The Student about Thinking Skill of The Whole of State Islamic Senior High School in Purwokerto City Indonesia. International Journal of Education and Research, 4 (10), 131-144.

[6] Assegaff, Asani dan Sontani, Tatang. (2016). Upaya Meningkatkan Kemampuan Berpikir Analitis melalui Model Problem Based Learning (PBL). Jurnal Pendidikan Manajemen Perkotaan, 1 (1), 40-51.

[7] Septyadini, Dita; Saputro, Sulistyo; dan Suryadi Budi. (2017). Komparasi Problem Soving dan Group Investigation Dilengkapi Catatan Terbimbing Ditinjau dari Kemampuan Analisis pada Materi Hukum-Hukum Dasar Kimia Kelas $X$ SMA N 1 Boyolali Tahun Ajaran 2015/2016. Jurnal Pendidikan Kimia, 6 (1), 84-93.

[8] Suryabrata, Sumadi. (2004). Psikolgi Pendidikan. Jakarta: PT RajaGrafindo Persada.

[9] Utami, Budhi. (2015). Pengaruh Penerapan Model Pembelajaran Gl untuk Meningkatkan Kemampuan Berpikir Analisis dan hasil Belajar pada Siswa Kelas X4 pada Materi Kingdom Animalia di SMA Daha Kediri. Prossiding Seminar Nasional XII Pendidikan Biologi FKIP UNS, 222-224.

[10] Sandi, S; Cooper, M; and Stevens, R. (2012) Effect of Cooperative Problem-Based Lab Instruction on Metacognition and ProblemSolving Skills. Journal of Chemical Education, 89, 700-706. 